\title{
GIFT, transnational corporations and the sixth mass extinction
}

Roger Shrimpton, Adjunct Professor, Dept. of Global Community Health and Behavioural Sciences, Tulane School of Public Health and Tropical Medicine, New Orleans, Louisiana, USA.

It is now abundantly clear that our food systems are no longer fit for purpose because of the enormous damage they are doing to the environment and human health ${ }^{1}$. A Great Intergenerational Food Transformation (GIFT) has been proposed with the aim of transforming the food system within one generation for the sake of future generations ${ }^{2}$. But transforming food systems to reduce their multiple negative impacts will require major changes in the power dynamics between players, not least among the commercial food sector that is currently the dominant barrier to action. Creating public demand for these changes is essential, but also the greatest challenge GIFT faces.

While there is growing public recognition that the problem of climate change is real, there is as yet little if any awareness that something potentially equally serious is threatening humanity, namely the "sixth mass extinction"3. The world's foremost experts are warning that the annihilation of wildlife is now an emergency that threatens civilisation, with $60 \%$ of mammals, birds, fish and reptiles already wiped out since $1970^{4}$. But perhaps the most worrying aspect is that insect biodiversity is declining at the fastest rate and a third of insect species are already threatened with extinction ${ }^{5}$. The main drivers of these declines include habitat loss due to conversion to intensive agriculture as well as pollution with synthetic insecticides and fertilizers. Unless we change our ways of producing food, insects as a whole will go down the path of extinction in a few decades, with potentially catastrophic consequences for the planet's ecosystem.

Due to what has been described as "policy inertia”, little progress has been made in tackling any of the three components of the so-called Global Syndemic, namely undernutrition, overnutrition and climate change ${ }^{6}$. Policy inertia includes the combined effects of inadequate political leadership and governance to enact the policies needed, as well as the lack of demand for policy action by the public, combined with strong

\footnotetext{
${ }^{1}$ Shrimpton R. 2017. Fixing our food system: an imperative for achieving sustainable development. World Nutrition. 8 (2): 207-231.

${ }^{2}$ Swinburn B. 2019. Power dynamics in $21^{\text {st }}$ century food systems. Nutrients. 11, 2544, 1-10.

${ }^{3}$ Ceballos, G., Ehrlich, P.R., Barnosky, A.D., Garcia A., Pringle, R.M., Palmer, T.M. 2015. Accelerated modern human-induced species losses: Entering the sixth mass extinction. I. Sci. Adv. 1:e1400253.

${ }^{4}$ WWF. 2018. Living Planet Report - 2018: Aiming Higher. Grooten, M. and Almond, R.E.A.(Eds). WWF, Gland, Switzerland.

${ }^{5}$ Sánchez-Bayoa,F , Wyckhuys, K.A.G. 2019. Worldwide decline of the entomofauna: A review of its drivers. Biological Conservation 232: 8-27

${ }^{6}$ Swinburn, B.A., Kraak, V.I., Allender, S., et al. 2019. The Global Syndemic of Obesity, Undernutrition and Climate Change: The Lancet Commission Report. The Lancet 393:791-846.
} 
opposition to those policies by powerful commercial interests. Those with the greatest commercial interests, and the ones that would lose most if we were to tackle the three pandemics, are the various transnational corporations that make their profits along the food chain.

Agricultural productivity was greatly increased during the post war years thanks to the green revolution ${ }^{7}$. The benefits of the revolution were concentrated among the richer larger landholders however, as the poorer farmers of the peasant food web could not afford to pay for these "improved" technological inputs ${ }^{8}$. The green revolution thus gave impetus to the development of the industrial agricultural system, or agribusiness ${ }^{9}$. This over time increased the flow of food crops from the places of production to the place of consumption by increasing numbers of families living in urban areas ${ }^{10}$. The number of companies providing the inputs to achieve increased production of food through the industrial agricultural system is very limited ${ }^{11}$. The "Big Six" mega seed and chemical crop players, (namely, BASF, Bayer, Dow, DuPont, Monsanto and Syngenta) control $75 \%$ of the global agrochemical market, $63 \%$ of the commercial seed market and over $75 \%$ of all private sector research and development in the sector ${ }^{12}$.

There has also been considerable growth in the international trading of agricultural commodities in the last two decades. The mean value of global agricultural trade totalled US $\$ 522$ billion per year from 2000 to $2009^{13}$, which corresponded to $26 \%$ of world gross agricultural production, based on farm gate prices. The amount of food calories traded on the international market was about 20\% of what was grown in 2009 and had more than doubled since $1986^{14}$. Food accounts for 10 percent of all global trade ${ }^{15}$ and the annual aggregate value of agricultural exports was expected to reach a record US\$1.29 trillion in 2011. Policies of trade liberalization have facilitated the rising availability and consumption of relatively cheap meat, dairy products and processed foods in Lower- and Middle-Income Countries (LMICs) ${ }^{16}$.

Imported foods tend to be cheaper because of continued state support to the industrial agriculture system in Higher Income Countries (HICs), and their dumping of cheaper food commodities onto the world market. Subsidies of around US\$ 600 billion were

\footnotetext{
${ }^{7}$ Evenson, R.E, \& Gollin, D. 2003. Assessing the Impact of the Green Revolution, 1960 to 2000. Science 300 (5620): 758-762.

8 Pingali PL. 2012. Green Revolution: Impacts, limits, and the path ahead. PNAS 109(31): 12302-12308

${ }^{9}$ Engdahl FW. 2007. Seeds of destruction: The hidden agenda of genetic manipulation. Montreal: Centre for Research on globalization.

${ }^{10}$ Oosterveer P, Sonnenfeld DA. 2012. Food, Globalization and Sustainability. London: Earthscan

${ }^{11}$ ETC Group. 2013. Putting the Cartel Before the Horse....and Farm, Seeds, Soil and Peasants, etc: Who Will Control Agricultural Inputs? Communiqué 111. The State Of Corporate Concentration. Ottawa: Action Group on Erosion, Technology and Concentration

${ }^{12}$ ETC Group, 2015. Breaking Bad: Big Ag Mega-Mergers in Play Dow + DuPont in the Pocket? Next: Demonsanto? ETC Group Communiqué 115. Val David, Canada.

${ }^{13}$ FAO, 2013. FAOSTAT. Rome: Food and Agriculture Organization of the United Nations

${ }^{14}$ D'Odorico P, Carr JA, Laio F, Ridolfi FL,Vandoni S (2014), Feeding humanity through global food trade. Earth's Future, 2: 458-469.

${ }^{15}$ FAO. 2011. Global food losses and food waste - Extent, causes and prevention. Rome: Food and Agriculture Organization of the United Nations.

${ }^{16}$ Thow, A. M. \& Hawkes, C. 2009 The implications of trade liberalization for diet and health: a case study from Central America. Global Health 28, 5. 1-15.
} 
transferred annually by 49 countries to domestic agricultural producers during the period 2012-14. The European Union and the United States government together spent around US\$ 70 billion in 2010 to subsidize mainly large-scale farmers to produce grains such as corn, soy and wheat ${ }^{17}$, most of which were used to intensively rear animals in factory farms. About a third of global cereal production and just over $90 \%$ of soybean production is used to feed farm animals ${ }^{18}$. The subsidies are provided to keep meat prices cheaper, despite the knowledge that the greater the support to animal based food systems the greater the environmental footprint ${ }^{19}$.

The food industry is now a massive business, with ten big food and beverage companies generating revenues of more than US\$1.1billion a day ${ }^{20}$. Together they are part of an industry valued at US\$7 trillion, larger than the energy sector and representing roughly ten percent of the global economy. Globally, processed foods account for 80 percent of country level food sales through retail outlets ${ }^{21}$. Global dietary diversity is decreasing, with 80 percent of the population consuming just four staple foods, which are wheat, rice, maize, and potatoes. These four staple foods are transformed into a vast array of processed food products, with more than 1,500 produced from wheat alone ${ }^{22}$. In 2000, the food industry spent US $\$ 20$ billion on food additives, and the average consumption was $7 \mathrm{~kg}$ per person a year in industrialized countries ${ }^{23}$. At that time the top three food processing companies (Nestle, Kraft, and ConAgra) had a combined annual global food sales of US $\$ 97$ billion $^{24}$.

Ultra-processed food (UPF) products are becoming dominant in the global food system ${ }^{25}$ contributing almost $60 \%$ of the energy and $90 \%$ of added sugars consumed by the USA population for example ${ }^{26}$. UPFs are industrial formulations made almost entirely from substances derived from foods and additives, with little, if any, intact

\footnotetext{
${ }^{17}$ Ortiz I, Chai J, Cummins M. 2011. Escalating food prices: the threat to poor households and policies to safeguard a recovery for all. UNICEF Social and economic policy working paper. New York: UNICEF ${ }^{18}$ FAO 2002. World Agriculture: Towards 2015/2030. Rome: Food and Agriculture Organization of the United Nations.

${ }^{19}$ Aleksandrowicz L, Green R, Joy E.J.M, Smith P, Haines A. 2016. The Impacts of Dietary Change on Greenhouse Gas Emissions, Land Use, Water Use, and Health: A Systematic Review. PLoS ONE 11(11): e0165797. doi:10.1371/journal. pone.0165797

${ }^{20}$ OXFAM 2013. Behind the brands. OXFAM Briefing Paper 166. Oxford: OXFAM International.

${ }^{21}$ Mazzocchi M, Shankar B, Traill B. 2012. The development of global diets since ICN 1992: influences of agri-food sector trends and policies. FAO COMMODITY AND TRADE POLICY RESEARCH WORKING PAPER No. 34. Rome: Food and Agriculture Organization of the United Nations.

${ }^{22}$ Henry CJK., \& Heppel NJ. 1998. "Introduction: From Foraging to Farming to Food Technology." In Nutritional Aspects of Food Processing and Ingredients, Eds Henry CJK, Heppell NJ. Aspen Publishers, Gaithersburg, Maryland, US.

${ }^{23}$ Millstone E., Lang, T. 2003. The Atlas of Food. Who Eats What, Where and Why. Earthscan publications, London.

${ }^{24}$ Lang, T and Heasman M. 2004. Food Wars. The global battle for mouths, minds and markets. London. Earthscan.

25 Monteiro CA, Moubarac JC, Cannon G, Ng SW, Popkin B. 2013. Ultra-processed products are becoming dominant in the global food system. Obesity Reviews 14 (Suppl. 2), 21-28

${ }^{26}$ Martínez Steele E, Baraldi LG, Louzada M L da C, Moubarac JC, Mozaffarian D, Monteiro CA. 2016. Ultra-processed foods and added sugars in the US diet: evidence from a nationally representative crosssectional study. BMJ Open 2016;6: e009892. doi:10.1136/ bmjopen-2015-00989.
} 
natural food ${ }^{27}$. Although spending on processed foods is still lower in LMICs (US\$143 per capita per year in middle income countries and US\$63 per capita in low-income countries), it is growing at 28 percent and 13 percent a year respectively in those country groups.

Transforming to healthy and sustainable diets by 2050 will require substantial dietary shifts, including a greater than $50 \%$ reduction in the global consumption of unhealthy foods such as red meat and sugar, as well as a greater than $100 \%$ increase in the consumption of healthy foods such as nuts, fruits, vegetables, and legumes in replacement of UPFs especially ${ }^{28}$. It is likely that improving diets in this way will make them cost more ${ }^{29}$, but this could be controlled by removing some of the subsidies currently going to the industrial agricultural food system and using these funds to incentivize the local production of healthy foods. Agricultural policies need to move towards strategic investments that can help deliver sustainable productivity growth and increased resilience, thereby increasing income opportunities for small farm households in more countries ${ }^{30}$.

The Framework Convention on Food Systems that has been proposed for $2020^{31}$ is urgently needed to promote healthy eating and environmentally sustainable agriculture. Such a framework should cover the wide range of policies required for comprehensive action in order to improve availability and access of healthy food, reduce poverty and inequalities, reduce greenhouse gas emissions as well as the use of fertilizers and pesticides in the industrial agricultural system. The framework can build on the UN Decade of Action on Nutrition and the commitments of the Rome Declaration on Nutrition and the recommendations included in the ICN2 Framework for Action ${ }^{32}$.

Government policy leadership is critical to achieving the rules, economic incentives and disincentives and expectations for food systems' transformation. To counter the undermining influence of vested commercial interests in creating this policy environment, civil society needs to increase its role in demanding policy action and holding the main actors to account for their actions and inactions. Nation states must be required by the convention to report periodically on how they are doing in implementing measures to ensure that their populations are being increasingly enabled to eat healthy and sustainable diets that will no longer contribute to causing the sixth mass extinction. And all of this is incredibly urgent, i.e. it must be done by the current generation.

\footnotetext{
${ }^{27}$ Monteiro CA, Cannon G, Levy R, Moubarac J-C, Jaime P, Martins AP, Canella D, Louzada M, Parra D. 2016. Food classification.World Nutr 7:28-38.

${ }^{28}$ Willet, W., Rockstrom, J., Loken, B., et al. 2019. Food in the Anthropocene: The EAT-Lancet Commission on healthy diets from sustainable food systems. The Lancet. 393: 447-492.

${ }^{29}$ Hirvonen K, Bai Y, Headey, D., Masters, W.A. 2019. Affordability of the EAT-Lancet reference diet: a global analysis. Lancet Glob Health. https://doi.org/10.1016/ S2214-109X(19)30447-4

30 OECD. 2016. Agricultural Policies at a Glance. Background Note 3 C OECD 2016. OECD Meeting of Agriculture Ministers. Paris. OECD.

${ }^{31}$ Swinburn, B.A., Kraak, V.I., Allender, S., et al. 2019. The Global Syndemic of Obesity, Undernutrition and Climate Change: The Lancet Commission Report. The Lancet 393:791-846.

${ }^{32}$ WHO \& FAO, Food. 2018. Driving commitment for nutrition within the UN Decade of Action on Nutrition: policy brief. Geneva: World Health Organization.
} 